\title{
Water quality and zooplankton community of the Eme River, Umuahia, Southeast Nigeria
}

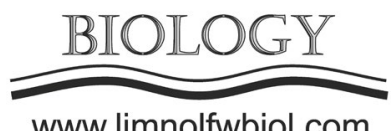

www.limnolfwbiol.com

\author{
Anyanwu E.D. ${ }^{1 * \oplus}$, Adetunji O.G. ${ }^{1 \oplus}$, Umeham S.N. ${ }^{2}$ \\ ${ }^{1}$ Department of Zoology and Environmental Biology, Michael Okpara University of Agriculture, Umudike, Nigeria \\ ${ }^{2}$ Department of Animal and Environmental Biology, Abia State University, Uturu, Nigeria
}

\begin{abstract}
Aquatic ecosystems and biota are often adversely affected by anthropogenic activities. Consequently, zooplanktons have been used to monitor anthropogenic impacts because of their sensitivity to their environment. Water quality and zooplankton community of the Eme River, Umuahia, was assessed between December 2017 and November 2018. The study was carried out in six stations in relation to human activities. Human activities in the watershed were dominated by sand mining. A quantitative filtration method was used for the zooplankton sample collection while standard sample collection and analytical methods were used for the water samples. The zooplankton species recorded were 27 while the most abundant zooplankton group was Rotifera. A known pollution indicator, Daphnia pulex, had the highest number of individuals. The effects of human activities in the watershed were reflected in the results of some of the physicochemical parameters of the river. The zooplankton assemblage and community structure also reflected the effects of human activities in the river. Combined effects of human activities and season contributed to the relatively low zooplankton abundance recorded particularly in some downstream stations. The impacts of sand mining on water quality and zooplankton were more remarkable in the downstream stations $(4-6)$ where the activity was intense while a large number of children swimming and related activities during the dry season had some impacts in station 1 . The dominance of indicator and tolerant species indicated that the river was undergoing eutrophication. Sand mining among other observed anthropogenic activities was a major contributor to the nutrient enrichment in the river. The major water quality parameters influencing the zooplankton community structure was revealed by canonical correspondence analysis.
\end{abstract}

Keywords: zooplankton, diversity, anthropogenic impact, bioindication, water quality, sand mining

\section{Introduction}

The water quality of the rivers is of considerable importance because they are generally used for multiple purposes (Venkatramanan et al., 2014). Freshwater bodies across the world have been subjected to intense human activities that have degraded the quality and utility of the water (Amah-Jerry et al., 2017). Water pollution is a serious problem in developing countries; adequate monitoring of water quality is necessary to appraise the suitability, assist management and control (Kozaki et al., 2020). The quality of the aquatic ecosystem and the ecological effects of human activities can be predicted by the assessment of its biological communities (Santos and Ferreira, 2020). One of the essential biological communities found in lotic freshwater ecosystems is zooplankton. Zooplankton is microscopic animals that serve as an important link in

*Corresponding author.

E-mail address: ekadon@yahoo.com (E.D. Anyanwu);

Received: December 1, 2021; Accepted: December 23, 2021; Available online: December 30, 2021 the conversion of energy from producers to consumers; playing an essential role in the aquatic food webs (Sharma et al., 2010; Schmidt et al., 2020). Zooplanktons are weak swimmers and usually drift along with the currents (Prygiel and Coste, 1993). They strongly respond to environmental changes and are used in the assessment of the conditions in aquatic ecosystems (Primo et al., 2015). Temporal and spatial variations of physicochemical environmental conditions often lead to dramatic and rapid changes in zooplanktons because they have a short life span and fast regeneration (Pace and Orcutt, 1981). Environmental parameters (dissolved oxygen (DO) and nutrients) are important for the presence and distribution of zooplankton. Low values of DO would limit their development. Nutrients $\left(\mathrm{NH}_{4}{ }^{+}\right.$and $\left.\mathrm{PO}_{4}{ }^{3-}\right)$ are important for their growth while $\mathrm{pH}$ and total suspended solids (TSS) are essential for their distribution (Duc et al., 2016). The efficiencies

(C) Author(s) 2021. This work is distributed under the Creative Commons AttributionNonCommercial 4.0 International License. 
of trophic transfer from phytoplankton to zooplankton and from zooplankton to fish depend largely on the taxa of zooplankton available in an aquatic ecosystem (Hairston and Hairston, 1993). A decline in zooplankton diversity in aquatic ecosystems will ultimately affect higher trophic levels. This will result in loss of species, habitat or even ecosystems and ecosystem services if there is no control (Gaygusuz and Dorak, 2013). Some anthropogenic activities take place at the Eme River, of which illegal and indiscriminate sand mining is the major. The objective of this study was to assess the water quality and zooplankton diversity vis-à-vis anthropogenic activities.

\section{Materials and methods}

\subsection{Study area}

The Eme River is located in Umuahia, Abia State, Nigeria. It originated in Uzuakoli, flowed through some communities and fell into the Imo River at Onuimo. The section studied is from Ofeme to Umudiawa across the Port Harcourt - Enugu expressway in Umuahia; about $3.25 \mathrm{~km}$ in length and situated between latitude $5^{\circ} 38^{\prime}$ and $5^{\circ} 37^{\prime} \mathrm{N}$ and longitude $7^{\circ} 25^{\prime}$ and $7^{\circ} 26^{\prime} \mathrm{E}$ (Fig. 1). The study area is characterized by mean annual rainfall $(4000 \mathrm{~mm})$, high relative humidity $(>70 \%)$ and high temperature $\left(29-31^{\circ} \mathrm{C}\right)$. There are two main seasons in the area: wet (June to November) and dry (December to May), with double maximum rainfalls recorded in July and September. "August break" is a short period of dryness usually occurring in between the peaks.

\subsection{Sampling stations}

Six sampling stations were selected in the river based on accessibility and human activities. Five of the stations were within the dredged section, except for station 1 . Station 1 is upstream, and the reference site is located in Mbato, Ofeme community. The substrate is muddy. A large number of children was observed swimming during the dry season up to early rains due to the proximity to the village, easy accessibility and low water depths. Other activities observed include washing of clothes and extraction of water for domestic purposes during the dry season. Station 2 is about $1.84 \mathrm{~km}$ downstream of station 1 and located at the outsketch of Ofeme community at Eme - Ihite. The substrate is a mixture of sand and stones. It was a less active or abandoned sand mining site, and minimal washing of clothes, swimming and extraction of water for domestic purposes were observed during the dry season. Station 3 is located at Eme - Ihite, towards the expressway, about $419.67 \mathrm{~m}$ downstream of station 2 . Large clayey boulders dominated the substrate. The only activity observed was periodic boat movements of sand miners across the station. Station 4 is about $490.26 \mathrm{~m}$ downstream of station 3 and is located in the Umudiawa community across the expressway. The substrate was sandy. An intensive sand mining and two sand landing sites were located upstream of the station. Station 5 is about $200.22 \mathrm{~m}$ downstream of station 4, within the Umudiawa community. Sand mining was observed because the substrate is sandy. Station 6 is about $300.14 \mathrm{~m}$ downstream of station 5 , within Umudiawa community. The substrate was sandy. Sand mining was observed in the river channel and banks.

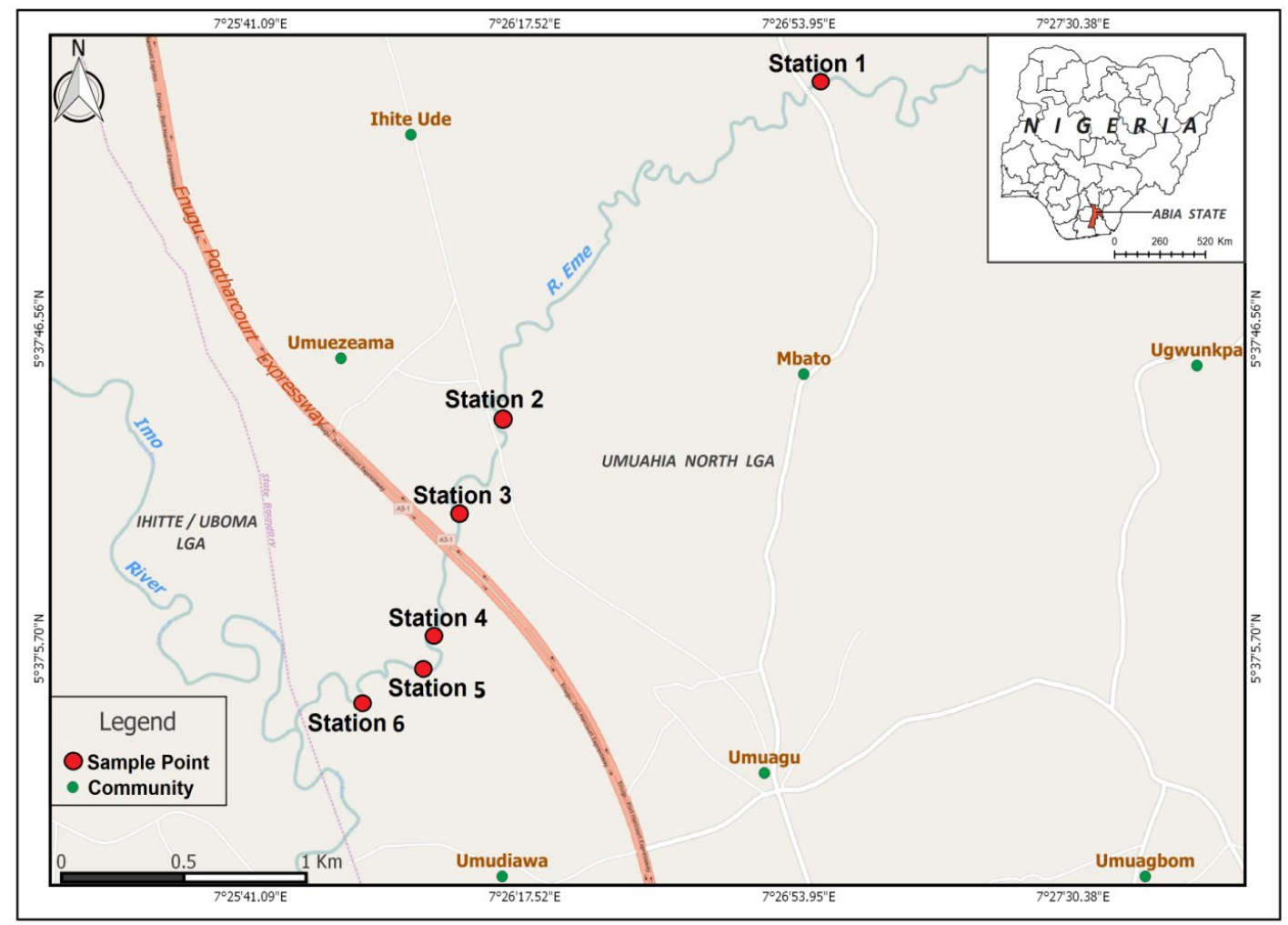

Fig.1. Map of Umuahia, Abia State, Nigeria, showing the sampling stations on the Eme River. 


\subsection{Samples collection and analysis}

This study was carried out between December 2017 and November 2018. Samples for water quality and zooplankton analyses were collected once a month. One litre water sampler was used for the sample collection, transferred into sterilized 1 litre plastic bottles and taken to the laboratory for analyses in ice chests. Water temperature (mercury-in-glass thermometer), flow velocity (floatation method), transparency (Secchi disk), $\mathrm{pH}$, electrical conductivity, and total suspended solids ( $\mathrm{pH} / \mathrm{EC} / \mathrm{TDS}$ Meter- HANNA 3100 model) were determined in situ while others were determined in the laboratory using standard methods described by APHA (2012) - dissolved oxygen and biochemical oxygen demand (Winkler's method with azide modification method), nitrate (UV spectrophotometric method), and phosphate (Stannous Chloride Method).

The quantitative filtration method was used for zooplankton sample collection. One hundred litres of water from undisturbed sections of each station were collected and filtered through a $55 \mu \mathrm{m}$ Hydro-Bios plankton net as a composite sample. The net content was poured into plankton bottles $(250 \mathrm{~mL})$ and preserved in a $4 \%$ formalin solution. A subsample (1 $\mathrm{mL}$ ) of the preserved sample was taken using a pipette. The collected sample was put on the Sedgwick-rafter counting chamber and viewed under a light binocular microscope (Nikon 400 binocular microscope) using a low magnification of $\mathrm{x} 10$. The zooplankton was sorted into different groups, and the cells per ml were counted. The identification was done to the lowest practicable taxonomy using key literature by Jeje and Fernando (1986) and Dang et al. (2015).

\subsection{Data analysis}

The results were summarized using a descriptive statistic package of Microsoft Excel. One-way ANOVA was used to test for statistical differences among the stations while Tukey's pairwise test was used for post hoc analysis. The zooplankton community structure was analysed using Margalef (D), ShannonWeiner $(H)$ and Evenness $(E)$ indices while canonical correspondence analysis (CCA) was used to determine the relationship between the zooplankton groups and some environmental variables.

\section{Results and discussion}

\subsection{Spatial and temporal variations of physico- chemical parameters}

The summary of the physicochemical parameters is presented in Table 1 . The water temperatures were moderate and ranged between 22.0 and $28.5^{\circ} \mathrm{C}$. The lowest value was recorded in station 1 (May 2018) while the highest value was recorded in station 6 (April 2018). The ambient surface water temperatures were influenced by seasons and sampling periods. An early rain event was responsible for the lowest temperature recorded in May 2018 while the highest temperature in
April 2018 was due to the dry season. Air temperatures are the major determinant of surface water temperatures (Park et al., 2016), and water temperature is a critical factor in some biotic and abiotic processes in the aquatic environment (Dugdale et al., 2018).

The flow velocity was moderate $(0.21-0.85 \mathrm{~m} / \mathrm{s})$. Station 1 had the lowest value in April 2018, and the highest one was recorded in station 3 in December 2017. Stations 2 and 3 were significantly higher $(F=31.59$; $P<0.05$ ). Flow velocity can significantly influence the self-purification capacity of a waterbody (Chapman and Kimstach, 1996). Flow velocity can considerably affect the composition, abundance and distribution of aquatic biota (Brooks et al., 2005; Oldmeadow et al., 2010). CCA also showed that flow velocity was a strong negative factor especially in station 3 . Increased flow velocity and river discharge can result in low species composition and abundance due to low residence time, especially in the wet season (Anyanwu et al., 2013).

The turbidity values ranged between 0.5 and 9.4 NTU; some exceeded the acceptable limit (5 NTU) of the Federal Ministry of Environment (FMEnv., 2011) in all the stations. The turbidity values exceeding limits in all the stations, especially between December 2017 and March 2018, could be attributed to the cumulative effect of receding flood and anthropogenic activities. The lowest and highest values were both recorded at station 4 in March and February 2018, respectively. High turbidity values were recorded at station 1 during the dry season due to a large number of children swimming, bathing, washing, and extraction of water for drinking. The station was shallow during the dry season and located close to the community. However, relatively higher values were recorded at stations 4 6 between May and November 2018 because of the effect of sand mining activities that increased with the intensity of rains (Anyanwu and Umeham, 2020). This was more remarkable in station 4 that was immediately downstream of sand mining and landing sites with a steady decline further downstream (Seiyaboh et al., 2013). CCA also showed that turbidity had a negative effect on zooplankton at station 4.

The $\mathrm{pH}$ values were acidic (4.3 - 6.3) and did not comply with the acceptable limit. FMEnv. (2011) recommended 6.5 to 8.5 for aquatic life. The lowest $\mathrm{pH}$ was recorded at station 2 (June 2018) while the highest was recorded at station 1 (September 2018). These low $\mathrm{pH}$ values could be due to both geogenic (Anyanwu and Emeka, 2019) and anthropogenic influences (Akankali et al., 2017). Seiyaboh et al. (2013) reported that sand mining contributes to low $\mathrm{pH}$ in water bodies. Extremes of $\mathrm{pH}$ cannot be tolerated by most aquatic organisms. Aquatic biota is very sensitive to $\mathrm{pH}$ levels lower than 5 , which may result in death (Kale, 2016).

The electrical conductivity (EC) values ranged between 45.2 and $168.4 \mu \mathrm{S} / \mathrm{cm}$. The lowest value was recorded at station 2 (March 2018) while the highest value was recorded at station 5 (January 2018). The electrical conductivity (EC) values were moderate, but the upstream stations $(1-3)$ were significantly $(\mathrm{F}=29.59 ; p<0.05)$ lower than the downstream stations 
Table 1. Summary of physicochemical parameters of the Eme River, Umuahia, Nigeria.

\begin{tabular}{|c|c|c|c|c|c|c|c|c|}
\hline Parameter & $\begin{array}{c}\text { Stn } 1 \\
\mathrm{X} \pm \text { SEM }\end{array}$ & $\begin{array}{c}\text { Stn } 2 \\
\mathrm{X} \pm \text { SEM }\end{array}$ & $\begin{array}{c}\text { Stn } 3 \\
X \pm \text { SEM }\end{array}$ & $\begin{array}{c}\text { Stn } 4 \\
\mathrm{X} \pm \text { SEM }\end{array}$ & $\begin{array}{c}\text { Stn } 5 \\
\mathrm{X} \pm \text { SEM }\end{array}$ & $\begin{array}{c}\text { Stn } 6 \\
\mathrm{X} \pm \text { SEM }\end{array}$ & P-value & FMEnv. \\
\hline Water temperature $\left({ }^{\circ} \mathrm{C}\right)$ & $\begin{array}{l}24.8 \pm 0.59 \\
(22.0-28.0)\end{array}$ & $\begin{array}{l}24.9 \pm 0.54 \\
(22.5-28.2)\end{array}$ & $\begin{array}{l}24.8 \pm 0.53 \\
(23.0-28.2)\end{array}$ & $\begin{array}{l}24.9 \pm 0.51 \\
(23.2-28.4)\end{array}$ & $\begin{array}{l}24.4 \pm 0.53 \\
(23.0-28.3)\end{array}$ & $\begin{array}{l}24.8 \pm 0.53 \\
(22.9-28.5)\end{array}$ & $\mathrm{P}>0.05$ & $<40$ \\
\hline Turbidity (NTU) & $\begin{array}{c}4.2 \pm 0.61 \\
(1.5-9.3)\end{array}$ & $\begin{array}{c}3.5 \pm 0.52 \\
(1.3-8.1)\end{array}$ & $\begin{array}{c}3.0 \pm 0.48 \\
(0.6-5.4)\end{array}$ & $\begin{array}{l}5.0 \pm 0.72 \\
(0.5-9.4)\end{array}$ & $\begin{array}{l}3.9 \pm 0.61 \\
(0.7-7.8)\end{array}$ & $\begin{array}{l}4.1 \pm 0.56 \\
(0.9-6.9)\end{array}$ & $\mathrm{P}>0.05$ & 5 \\
\hline Flow velocity $\left(\mathrm{ms}^{-1}\right)$ & $\begin{array}{l}0.35 \pm 0.02^{\mathrm{a}} \\
(0.21-0.49)\end{array}$ & $\begin{array}{c}0.56 \pm 0.04^{\mathrm{b}} \\
(0.37-0.80)\end{array}$ & $\begin{array}{l}0.71 \pm 0.02^{\mathrm{c}} \\
(0.63-0.85)\end{array}$ & $\begin{array}{c}0.36 \pm 0.02^{\mathrm{a}} \\
(0.24-0.46)\end{array}$ & $\begin{array}{c}0.37 \pm 0.02^{\mathrm{a}} \\
(0.28-0.50)\end{array}$ & $\begin{array}{l}0.45 \pm 0.03^{\mathrm{a}} \\
(0.26-0.58)\end{array}$ & $\mathrm{P}<0.05$ & - \\
\hline $\mathrm{pH}$ & $\begin{array}{l}5.69 \pm 0.11 \\
(5.0-6.3)\end{array}$ & $\begin{array}{l}5.43 \pm 0.13 \\
(4.3-5.9)\end{array}$ & $\begin{array}{c}5.42 \pm 0.10 \\
(4.9-6.1)\end{array}$ & $\begin{array}{l}5.53 \pm 0.10 \\
(5.0-6.1)\end{array}$ & $\begin{array}{l}5.49 \pm 0.10 \\
(5.1-6.2)\end{array}$ & $\begin{array}{l}5.55 \pm 0.10 \\
(5.1-6.1)\end{array}$ & $\mathrm{P}>0.05$ & $6.5-8.5$ \\
\hline Electrical conductivity $\left(\mu \mathrm{Scm}^{-1}\right)$ & $\begin{array}{l}86.0 \pm 4.40^{\mathrm{a}} \\
(55.6-115.8)\end{array}$ & $\begin{array}{l}71.3 \pm 4.43^{a} \\
(45.2-95.4)\end{array}$ & $\begin{array}{l}65.7 \pm 3.50^{\mathrm{a}} \\
(49.6-88.7)\end{array}$ & $\begin{array}{l}130.4 \pm 5.86^{b} \\
(90.3-160.2)\end{array}$ & $\left|\begin{array}{c}115.4 \pm 6.04^{b} \\
(88.5-168.4)\end{array}\right|$ & $\left|\begin{array}{c}119.6 \pm 5.38^{b} \\
(87.1-148.4)\end{array}\right|$ & $\mathrm{P}<0.05$ & - \\
\hline Dissolved oxygen $\left(\mathrm{MgL}^{-1}\right)$ & $\begin{array}{c}3.7 \pm 0.38 \\
(2.3-5.7)\end{array}$ & $\begin{array}{l}3.6 \pm 0.34 \\
(2.2-5.9)\end{array}$ & $\begin{array}{l}3.7 \pm 0.40 \\
(1.8-6.1)\end{array}$ & $\begin{array}{l}3.9 \pm 0.46 \\
(1.6-6.1)\end{array}$ & $\begin{array}{l}3.6 \pm 0.37 \\
(2.0-5.5)\end{array}$ & $\begin{array}{c}3.8 \pm 0.42 \\
(1.8-5.8)\end{array}$ & $\mathrm{P}>0.05$ & 6 \\
\hline $\begin{array}{c}\text { Biochemical oxygen } \\
\text { Demand }\left(\mathrm{MgL}^{-1}\right)\end{array}$ & $\begin{array}{c}1.7 \pm 0.14^{\mathrm{ab}} \\
(1.0-2.5)\end{array}$ & $\begin{array}{c}1.5 \pm 0.08^{\mathrm{b}} \\
(1.1-1.9)\end{array}$ & $\begin{array}{c}1.7 \pm 0.12^{\mathrm{b}} \\
(1.1-2.4)\end{array}$ & $\begin{array}{c}2.6 \pm 0.37^{\mathrm{ac}} \\
(0.8-4.3)\end{array}$ & $\begin{array}{c}1.9 \pm 0.20^{\mathrm{ab}} \\
(1.0-3.2)\end{array}$ & $\begin{array}{c}2.1 \pm 0.25^{\mathrm{ab}} \\
(0.9-3.9)\end{array}$ & $\mathrm{P}<0.05$ & 3 \\
\hline Nitrate $\left(\mathrm{MgL}^{-1}\right)$ & $\begin{array}{c}2.9 \pm 0.30^{\mathrm{b}} \\
(1.8-4.9)\end{array}$ & $\begin{array}{c}2.2 \pm 0.17^{\mathrm{b}} \\
(1.3-3.2)\end{array}$ & $\begin{array}{c}1.6 \pm 0.12^{\mathrm{a}} \\
(1.1-2.4)\end{array}$ & $\begin{array}{c}4.5 \pm 0.20^{c} \\
(3.4-5.6)\end{array}$ & $\begin{array}{c}2.6 \pm 0.37^{\mathrm{ab}} \\
(1.2-5.3)\end{array}$ & $\begin{array}{c}2.9 \pm 0.27^{b} \\
(1.9-5.2)\end{array}$ & $\mathrm{P}<0.05$ & 9.1 \\
\hline Phosphate $\left(\mathrm{MgL}^{-1}\right)$ & $\begin{array}{c}1.3 \pm 0.08^{\mathrm{a}} \\
(1.0-1.9)\end{array}$ & $\begin{array}{c}0.8 \pm 0.10^{\mathrm{a}} \\
(0.5-1.7)\end{array}$ & $\begin{array}{c}0.7 \pm 0.07^{\mathrm{a}} \\
(0.4-1.2)\end{array}$ & $\begin{array}{c}3.4 \pm 0.18^{\mathrm{b}} \\
(2.8-4.6)\end{array}$ & $\begin{array}{c}2.8 \pm 0.22^{\mathrm{bc}} \\
(1.9-4.3)\end{array}$ & $\begin{array}{c}2.9 \pm 0.21^{\mathrm{bc}} \\
(2.0-4.5)\end{array}$ & $\mathrm{P}<0.05$ & 3.5 \\
\hline
\end{tabular}

Note. a, b, c, d, e - Means with different superscripts across the rows are significantly different at p <0.05; SEM - Standard error of the mean; FMEnv. (2011) - National environmental (surface and groundwater quality control) regulations (2011).

$(4-6)$ due to the effects of sand mining activities in the downstream stations. Sand mining activities increase the levels of EC in surface water (Rehman et al., 2016) and usually contribute to an increase in water pollution. The relatively higher EC values recorded in station 1 compared to stations 2 and 3 could be attributed to perturbation from a large number of children swimming during the dry season as well as allochthonous inputs in the wet season from increased runoffs.

Dissolved oxygen is an essential parameter used in the assessment of water quality (Kale, 2016), and its level is very important to support biodiversity in aquatic ecosystems. Only two of the dissolved oxygen values exceeded the acceptable limit $(6 \mathrm{mg} / \mathrm{L})$ set by FMEnv (2011). The values ranged from 1.6 to $6.1 \mathrm{mg} / \mathrm{L}$; the lowest one was recorded in station 4 (November 2018), and the highest - in stations 3 (January 2018) and 4 (February 2018). Most of DO values were below the acceptable limit, especially in station 4 due to anthropogenic impact (sand mining). Rao et al. (2013) reported that some environmental impacts associated with sand mining activities such as re-suspension of nutrients and chemicals, altered water flow and increased water temperature can contribute to the depletion of oxygen in the water. CCA showed that dissolved oxygen was one of the major positive factors influencing the zooplankton community.

Biochemical Oxygen Demand (BOD) is another important parameter used in evaluating the health and self-purification capacity of freshwater bodies. BOD ranged between 0.8 and $4.3 \mathrm{mg} / \mathrm{L}$; the lowest and highest values were recorded in station 4 in November 2018 and February 2018, respectively. Some of the values, especially in the downstream stations $(4-6)$, exceeded the acceptable limit $(3 \mathrm{mg} / \mathrm{L})$. Station 4 was significantly different $(\mathrm{F}=3.43 ; p<0.05)$ from stations 2 and 3 . This is also due to sand mining activities. Akankali et al. (2017) observed that sand mining activities greatly increase the release and circulation of organic matter from the sediments into the water column, which can contribute to an increase in BOD levels.

Nitrate occurs naturally in many environments at moderate levels, except for those under the impact (Chapman and Kimstach, 1996). The nitrate values (1.1 - $5.6 \mathrm{mg} / \mathrm{L}$ ) were within the acceptable limit. The lowest value was recorded in station 3 (June 2018) while the highest value was recorded in station 4 (February 2018). Higher values were recorded in the downstream stations $(4-6)$, which could be caused by sand mining activities. In particular, station 4 was significantly higher $(\mathrm{F}=14.62 ; p<0.05)$ than the others. Akankali et al. (2017) recorded higher values $(10.7-12.4 \mathrm{mg} / \mathrm{L})$ in the Okoro Nsit stream, South South Nigeria that is also subjected to intense sand mining activities. The effect of a large number of children swimming during the dry season and allochthonous inputs during the wet season could be responsible for the elevated values in station 1 compared to stations 2 and 3 .

Phosphate exhibited the same trend as nitrate. The values ranged between 0.4 and $4.6 \mathrm{mg} / \mathrm{L}$, with the lowest values recorded in June and July 2018 (station 3 ) and the highest values in September 2018 (station $4)$. The values of the downstream stations $(4-6)$ exceeded the acceptable limit set by FMEnv. (2011) and were significantly $(\mathrm{F}=56.71 ; p<0.05)$ higher 
than the upstream stations $(1-3)$ values. This could be also caused by sand mining activities. Akankali et al. (2017) recorded lower values (2.5 to $3.6 \mathrm{mg} / \mathrm{L}$ ) in the Okoro Nsit stream, South South Nigeria. Relatively higher phosphate values were also recorded in station 1 compared to stations 2 and 3 as observed for nitrate and attributed to the same factors.

\subsection{Zooplankton composition, abundance and distribution}

The zooplankton species composition, abundance and distribution are presented in Table 2. A total of 3382 zooplankton individuals were recorded. The most abundant group was Rotifera (1064 individuals/L or $31.5 \%$ ) followed by Cladocera (961 individuals/L or $28.4 \%$ ), Protozoa (741 individuals/L or $21.9 \%$ ), and Copepod (616 individuals/L or $18.2 \%$ ). Rotifera was also reported as the dominant group in other Nigerian rivers subjected to intense sand mining
(Ekwu and Udo, 2014; Ekpo et al., 2015). Small size, parthenogenesis and rapid reproduction of rotifers under favourable conditions (nutrient-enriched water) could be responsible for their high abundance (Levine et al., 1999). Other factors include their morphological variations and adaptations (Wetzel, 2001) as well as their diverse feeding habits (Mustapha, 2009). Rotifers minimize competition through niche exploitation and food utilization owing to their ability to migrate vertically, which could also be responsible for their dominance (Ekpo et al., 2015).

The number of species recorded was higher than 4 and 8 species recorded in the Odot stream and Ikpa River, respectively, in the Niger Delta, Nigeria, which were also subjected to sand mining activities (Ekwu and Udo, 2014; Ekpo et al., 2015). The relatively low zooplankton abundance could be attributed to anthropogenic impact exacerbated by seasonal influences. Arimoro and Oganah (2010) recorded a higher abundance (4322 individuals/1) in the Orogodo River of the Niger Delta, Nigeria, perturbed by abattoir effluent and sand mining activities.

Table 2. Species composition, abundance and distribution of zooplankton in the Eme River, Umuahia, Nigeria.

\begin{tabular}{|c|c|c|c|c|c|c|c|c|c|}
\hline Group & Taxa & Station 1 & Station 2 & Station 3 & Station 4 & Station 5 & Station 6 & Total & $\begin{array}{l}\text { RA } \\
(\%)\end{array}$ \\
\hline \multirow[t]{5}{*}{ Copepoda } & $\begin{array}{l}\text { Campthocamptus } \\
\text { staphylinus }\end{array}$ & 26 & 21 & 14 & 33 & 22 & 22 & 138 & 4.08 \\
\hline & Eucyclops speratus & 10 & 22 & 39 & 29 & 12 & 32 & 144 & 4.26 \\
\hline & Microcyclops varicans & 21 & 27 & 22 & 11 & 16 & 21 & 118 & 3.49 \\
\hline & Sinodiaptomus sarsi & 23 & 20 & 20 & 0 & 3 & 22 & 88 & 2.6 \\
\hline & Mesochra suifunensis & 24 & 18 & 26 & 16 & 10 & 34 & 128 & 3.78 \\
\hline \multirow[t]{7}{*}{ Cladocera } & Alona affins & 12 & 19 & 25 & 27 & 34 & 13 & 130 & 3.84 \\
\hline & Daphnia longis & 20 & 26 & 23 & 10 & 20 & 35 & 134 & 3.96 \\
\hline & D. pulex & 25 & 25 & 35 & 27 & 37 & 26 & 175 & 5.17 \\
\hline & D. magna & 26 & 26 & 25 & 12 & 22 & 28 & 139 & 4.11 \\
\hline & Moina dubia & 44 & 22 & 19 & 20 & 26 & 35 & 166 & 4.91 \\
\hline & M. micrura & 11 & 18 & 22 & 20 & 22 & 15 & 108 & 3.19 \\
\hline & $\begin{array}{l}\text { Diaphanosoma } \\
\text { Brachyurum }\end{array}$ & 21 & 15 & 19 & 27 & 20 & 7 & 109 & 3.22 \\
\hline \multirow[t]{8}{*}{ Rotifera } & Keratella cochlearis & 20 & 20 & 21 & 14 & 15 & 14 & 104 & 3.08 \\
\hline & Brachionus capsuliflorus & 20 & 26 & 12 & 25 & 23 & 35 & 141 & 4.17 \\
\hline & B. plicatilis & 16 & 24 & 18 & 25 & 17 & 30 & 130 & 3.84 \\
\hline & Asplanchna priodonta & 27 & 19 & 25 & 27 & 31 & 22 & 151 & 4.47 \\
\hline & Notholca labis & 15 & 36 & 14 & 11 & 33 & 22 & 131 & 3.87 \\
\hline & Synchaeta pectinata & 26 & 23 & 30 & 23 & 21 & 29 & 152 & 4.49 \\
\hline & Conochilus umcormis & 25 & 23 & 25 & 21 & 6 & 28 & 128 & 3.79 \\
\hline & Ascomorpha ecaudis & 29 & 30 & 20 & 13 & 17 & 18 & 127 & 3.76 \\
\hline \multirow[t]{8}{*}{ Protozoa } & Paramecium candatum & 15 & 21 & 13 & 12 & 24 & 20 & 105 & 3.11 \\
\hline & Difflugia candatum & 14 & 18 & 22 & 15 & 17 & 7 & 93 & 2.75 \\
\hline & Didinium bolbanic & 26 & 25 & 22 & 8 & 8 & 14 & 103 & 3.05 \\
\hline & Tintinnopsis lacustris & 17 & 27 & 12 & 20 & 23 & 25 & 124 & 3.67 \\
\hline & Amoeba radiosa & 11 & 17 & 12 & 13 & 11 & 23 & 87 & 2.57 \\
\hline & Vorticella radians & 20 & 30 & 17 & 24 & 18 & 32 & 141 & 4.17 \\
\hline & Arcella nitrata & 19 & 21 & 25 & 15 & 3 & 5 & 88 & 2.60 \\
\hline & Total & 563 & 619 & 577 & 498 & 511 & 614 & 3382 & \\
\hline
\end{tabular}


The most abundant zooplankton recorded was Daphnia pulex (Cladocera) with 175 individuals/L (5.17\% of the total zooplankton abundance). Daphnia pulex is the most common cladoceran found almost in all permanent and eutrophic freshwater environments (Miller, 2000). The large body sizes of Daphnia makes it possible for them to graze on large quantities and diverse forms of phytoplankton; contributing to their predominance among the cladocerans (Mustapha, 2009), and their composition and abundance is also dependent on food supply (Miller, 2000).

Spatially, the most abundant individuals (619 individuals/L or $18.3 \%$ ) were recorded in station 2 followed by station 6 (614 individuals/L or $18.2 \%$ ), station 3 (577 individuals/L or $17.1 \%$ ), station 1 (563 individuals/L or $16.6 \%$ ), station 5 (511 individuals/L or $15.1 \%$ ), and station 4 (498 individuals $/ \mathrm{L}^{-1}$ or $14.7 \%)$. Little or no human activities were responsible for the high zooplankton abundance in station 2 while sand mining activities were responsible for the low abundance in station 4. Arimoro and Oganah (2010) recorded lower abundance in station 3, where sand mining occurred in contrast to station 1 (control) with no activity recorded. Station 6 showed signs of recovery after the impacts. Arimoro and Oganah (2010) observed that sensitive species usually disappears when water becomes polluted and recovers quickly downstream of the impact source while tolerant species survive stress associated with pollution and flourish. Ko et al. (2020) also reported a significant recovery in the number of species and individuals after dredging operations. High flow velocity could be also responsible for the relatively lower abundance in station 3. Planktonic organisms are continuously washed downstream by flowing water; therefore, their development is usually affected (Redden et al., 2009).

\subsubsection{Zooplankton community structure}

In the assessment of pollution and waterbody productivity using plankton, diversity indices have an important application (Hastuti et al., 2018). It is general knowledge that species diversity and richness are usually reduced as the perturbation increases; though some tolerant species tend to flourish (Xu et al., 2005). The zooplankton groups showed varied responses to the effects of anthropogenic activities as reflected in their community structures (Table 3 ).

Generally, Rotifera was the most abundant group while Copepoda was the least one. The abundance ranged between 63 individuals/L (copepoda, station 5) and 201 individuals/L (Rotifera, station 2). Lower abundance was recorded in stations 4 (Cladocera and Rotifera) and 5 (Copepoda and Protozoa). Highest abundance was recorded in stations 2 (Rotifera and Protozoa), 5 (Cladocera) and 6 (Copepoda). The abundance though varied among the groups was relatively higher at the less perturbed stations $(1-3)$ while lower abundances were recorded in the more perturbed stations (4 and 5) and station 6 showing signs of recovery (Ko et al., 2020).

Rotifera and Copepoda had the highest and lowest Shannon-Weiner diversity index (H), respectively. Among the Rotifera, station 2 had the highest value (2.059), and station 5 - the lowest value, (1.992) followed by station 4 (2.033). The highest ShannonWeiner diversity index $(\mathrm{H})$ was recorded in station 2 (1.600), and the lowest one - in station 4 (1.300) among the Copepoda. The Shannon-Weiner diversity indices were all low $(1-2)$, indicating some level of pollution. Station 2 had relatively higher values in all the zooplankton groups while station 6 showed signs of recovery in some groups. Water bodies are classified

Table 3. Community structure of zooplankton in the Eme River, Umuahia.

\begin{tabular}{|c|c|c|c|c|c|c|c|}
\hline Group & $\begin{array}{c}\text { Biodiversity } \\
\text { indices }\end{array}$ & $\begin{array}{c}\text { Station } \\
1 \\
\end{array}$ & $\begin{array}{c}\text { Station } \\
2 \\
\end{array}$ & $\begin{array}{c}\text { Station } \\
3 \\
\end{array}$ & $\begin{array}{c}\text { Station } \\
4\end{array}$ & $\begin{array}{c}\text { Station } \\
5\end{array}$ & $\begin{array}{c}\text { Station } \\
6\end{array}$ \\
\hline \multirow[t]{4}{*}{ Copepoda } & Individuals & 104 & 108 & 121 & 89 & 63 & 131 \\
\hline & Shannon-Weiner $(\mathrm{H})$ & 1.567 & 1.6 & 1.552 & 1.3 & 1.468 & 1.587 \\
\hline & Evenness (E) & 0.9583 & 0.9906 & 0.9445 & 0.9175 & 0.8685 & 0.9779 \\
\hline & Margalef (D) & 0.8613 & 0.8543 & 0.8341 & 0.6684 & 0.9655 & 0.8205 \\
\hline \multirow[t]{4}{*}{ Cladocera } & Individuals & 159 & 151 & 168 & 143 & 181 & 159 \\
\hline & Shannon-Weiner $(\mathrm{H})$ & 1.85 & 1.928 & 1.925 & 1.888 & 1.916 & 1.833 \\
\hline & Evenness (E) & 0.909 & 0.9822 & 0.9795 & 0.9442 & 0.971 & 0.8934 \\
\hline & Margalef (D) & 1.184 & 1.196 & 1.171 & 1.209 & 1.154 & 1.184 \\
\hline \multirow[t]{4}{*}{ Rotifera } & Individuals & 178 & 201 & 165 & 159 & 163 & 198 \\
\hline & Shannon-Weiner $(\mathrm{H})$ & 2.055 & 2.059 & 2.042 & 2.033 & 1.992 & 2.044 \\
\hline & Evenness (E) & 0.9755 & 0.9797 & 0.9628 & 0.955 & 0.9162 & 0.965 \\
\hline & Margalef (D) & 1.351 & 1.32 & 1.371 & 1.381 & 1.374 & 1.324 \\
\hline \multirow[t]{4}{*}{ Protozoa } & Individuals & 122 & 159 & 123 & 107 & 104 & 126 \\
\hline & Shannon-Weiner $(\mathrm{H})$ & 1.913 & 1.927 & 1.905 & 1.895 & 1.809 & 1.804 \\
\hline & Evenness (E) & 0.9678 & 0.9813 & 0.9596 & 0.9504 & 0.872 & 0.868 \\
\hline & Margalef (D) & 1.249 & 1.184 & 1.247 & 1.284 & 1.292 & 1.241 \\
\hline
\end{tabular}


with Shannon-Weiner diversity Index as clean ( $>4.5)$, slightly polluted (4.5-3), moderately polluted (3$2)$, heavily polluted (2-1), and highly polluted $(<1)$ according to Zheng et al. (2007).

Margalef Species Richness index had a similar trend with Shannon-Weiner Diversity Index $(\mathrm{H})$ among the groups; though, there were differences in the spatial variations. Among the Rotifera, station 4 had the highest value (1.381) followed by station 5 (1.374) while the relatively unperturbed station 2 (1.300) and station 6 (1.324) had lower values. The highest Margalef Species Richness index among the Copepoda was recorded in station 5 (0.9655), and the lowest in station 4 (0.6684). The values were generally low in all the stations and among the groups indicating some level of perturbation (Shah and Pandit, 2013). The more perturbed stations had higher values than the less perturbed stations, especially among Rotifera and Protozoa. Meng et al. (2020) explained this observation that the Margalef index concentrates on the richness and taxonomic composition instead of community abundance.

The evenness index did not show any trend, though the highest values were recorded in station 2 in all the groups while the lowest values were recorded in stations 5 (Copepoda, 0.8685 and Rotifera, 0.9162) and 6 (Cladocera, 0.8934 and Protozoa, 0.8680). The evenness index indicates how the organisms are evenly distributed in a sample (Kaparapu and Geddada, 2013). Evenness values were relatively higher in station 2 in all the groups, indicating the effect of the anthropogenic activities in the other stations. However, flow velocity could be responsible for the values recorded in station 3 (Redden et al., 2009) and anthropogenic activities other than sand mining in station 1 . Generally, the upstream stations $(1-3)$ were relatively higher, indicating the negative impact of sand mining in the downstream stations $(4-6)$.

\subsubsection{Relationship between zooplankton groups and environmental variables}

CCA showed that water temperature, flow velocity and dissolved oxygen exerted a greater positive influence on the relative abundance of the zooplankton groups compared to the higher negative influence exerted by electrical conductivity, phosphate and turbidity (Fig. 2). Flow velocity exerted a positive influence on Copepoda while biochemical oxygen demand exerted a negative influence on Rotifera and Cladocera. Spatially, dissolved oxygen exerted a positive influence on stations 3 and 6 while electrical conductivity, phosphate and turbidity exerted a negative influence on stations 1 and 4 .

\section{Conclusions}

Some of the physicochemical parameters showed that the river was perturbed by the anthropogenic activities in the watershed especially in the downstream stations where sand mining was intense. The zooplankton assemblage and community structure also indicated some levels of perturbation. The relatively low zooplankton abundance, especially in some downstream stations, could be due to anthropogenic impact exacerbated by seasonal influences. The presence of some eutrophic indicators and tolerant species especially cladocerans showed that the river was undergoing eutrophication. Sand mining among other observed anthropogenic activities was a major contributor to the nutrient enrichment in the river. Therefore, it needs to be regulated.

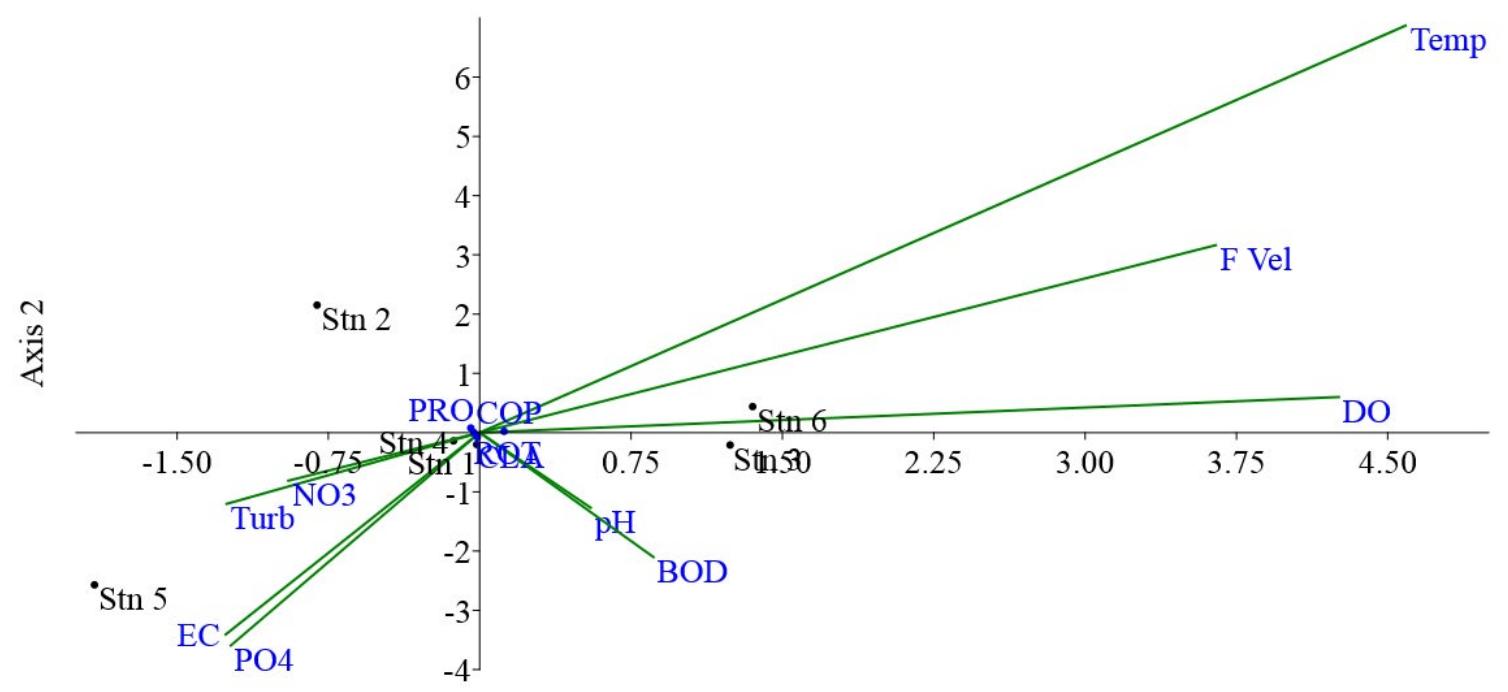

Axis 1

Fig.2. Canonical correspondence analysis (CCA) ordination showing relationships between zooplankton groups, stations and environmental variables. BOD - biochemical oxygen demand, DO - dissolved oxygen, Turb - turbidity, Temp - water temperature, $\mathrm{NO}_{3}$ - nitrates, $\mathrm{PO}_{4}$ - phosphates, EC - electrical conductivity, FVel - flow velocity, ROT - Rotifer, COP - Copepod, CLA Cladocera, and PRO - Protozoa. 


\section{Acknowledgements}

Thanks to Mr Emeka Nwachukwu for assistance with the sample collections, Mr Emmanuel Irozuru for assisting in the identification of the zooplankton samples and Mr Chinedu Ogbodo for producing the study map.

\section{Conflict of interests} interests.

The authors declare that they have no competing

\section{References}

Akankali J.A., Idongesit A.S., Akpan P.E. 2017. Effects of sand mining activities on water quality of Okoro Nsit stream, Nsit Atai Local Government Area, Akwa Ibom State, Nigeria. International Journal of Development and Sustainability 6: 451-462.

Amah-Jerry E.B., Anyanwu E.D., Avoaja D.A. 2017. Anthropogenic impacts on the water quality of Aba River, Southeast Nigeria. Ethiopian Journal of Environmental Studies and Management 10(3): 299-314. DOI: 10.4314/ ejesm.v10i3.3

Anyanwu E.D., Emeka C.S. 2019. Application of water quality index in the drinking water quality assessment of a southeastern Nigeria river. Food and Environmental Safety 18(4): 308-314.

Anyanwu E.D., Ikomi R.B., Arimoro F.O. 2013. Water quality and zooplankton of the Ogba River, Benin City, Nigeria. African Journal of Aquatic Science 38(2): 193-199. DOI: $10.2989 / 16085914.2013 .784697$

Anyanwu E.D., Umeham S.N. 2020. Identification of waterbody status in Nigeria using predictive index assessment tools: a case study of Eme River, Umuahia, Nigeria. International Journal of Energy and Water Resources 4: 271-279. DOI: 10.1007/s42108-020-00066-5

APHA (2012). Standard Methods for the Analysis of Water and Wastewater, 23 ${ }^{\text {rd }}$ Edition. Washington D.C: American Public Health Association.

Arimoro F.O., Oganah A.O. 2010. Zooplankton community responses in a perturbed tropical stream in Niger Delta, Nigeria. The Open Environmental \& Biological Monitoring Journal 3: 1-11. DOI: 10.2174/1875040001003010001

Brooks A.J., Haeusler T., Reifelds I. et al. 2005. Hydraulic microhabitats and distribution of macroinvertebrate assemblages in riffles. Freshwater Biology 50(2): 331-334. DOI: $10.1111 /$ j.1365-2427.2004.01322.x

Chapman D., Kimstach V. 1996. Selection of water quality variables. In: Chapman D. (Ed.)., Water quality assessment: a guide to the use of biota, sediments and water in environmental monitoring ( $2^{\text {nd }}$ Edition). London and New York: Taylor and Francis, pp. 74-132.

Dang P.D., Khoi N.V., Nga L.N. et al. 2015. Identification handbook of freshwater zooplankton of the Mekong River and its tributaries. Vientiane: Mekong River Commission.

Duc P.A., Linh N.T.M., Thanh D.M. 2016. Zooplankton from Can Giuoc River in Southern Vietnam. GeoScience Engineering, 62(3): 27-33. DOI: 10.1515/gse-2016-0022

Dugdale S.J., Allen Curry R., St-Hilaire A. et al. 2018. Impact of future climate change on water temperature and thermal habitat for keystone fishes in the Lower Saint John River. Water Resources Management 32(15): 4853-4878. DOI: $10.1007 / \mathrm{s} 11269-018-2057-7$

Ekpo I.E., Essien-Ibok M.A., Duncan A.O. 2015. Densities, spatial distribution and community structure of plankton of
Odot Stream. Journal of Ecology and the Natural Environment 7(6): 180-187. DOI: 10.5897/JENE2015.0521

Ekwu A.O., Udo N.D. 2014. Plankton communities of Ikpa River, Southeast Nigeria exposed to sand-dredging activities. Journal of Fisheries and Aquatic Science 9(5): 345-351. DOI: 10.3923/jfas.2014.345.351

FMEnv. 2011. National environmental (surface and groundwater quality control) regulations, S.I. No. 22, Gazette No. 49, Vol. 98 of $24^{\text {th }}$ May, 2011. Federal Ministry of Environment, Abuja, Nigeria.

Gaygusuz Ö., Dorak Z. 2013. Species composition and diversity of the zooplankton fauna of Darlik Stream (İstanbulTurkey) and its tributaries. Journal of FisheriesSciences.com 7(4): 329-343. DOI: 10.3153/jfscom.2013037

Hairston Jr N.G., Hairston Sr N.G. 1993. Causeeffect relationships in energy flow, trophic structure, and interspecific interactions. American Naturalist 142(3): 379-411. DOI: $10.1086 / 285546$

Hastuti A.W., Pancawati Y., Surana I.N. 2018. The abundance and spatial distribution of plankton communities in Perancak Estuary, Bali. IOP Conference Series: Earth and Environmental Science 176. DOI: 10.1088/1755-1315/176/1/012042

Jeje C.Y., Fernando C.H.A. 1986. Practical guide to the identification of Nigerian zooplankton. Kainji, Nigeria: Kainji Lake Research Institute Press.

Kale V.S. 2016. Consequence of temperature, $\mathrm{pH}$, turbidity and dissolved oxygen water quality parameters. International Advanced Research Journal in Science, Engineering and Technology 3(8): 186-190. DOI: $10.17148 /$ IARJSET.2016.3834

Kaparapu J., Geddada M.N.R. 2013. Seasonal distribution of phytoplankton in Riwada reservoir, Visakhapatnam, Andhra Pradesh, India. Notulae Scientia Biologicae 5(3): 290-295. DOI: $10.15835 / \mathrm{nsb539082}$

Ko E.J., Kim D-K., Jung E-S. et al. 2020. Comparison of zooplankton community patterns in relation to sediment disturbances by dredging in the Guemho River, Korea. Water 12: 3434. DOI: $10.3390 / w 12123434$

Kozaki D., Rahim M.H.A., Ishak W.M.F. et al. 2020 Assessment of the river water pollution levels in Kuantan, Malaysia, using ion-exclusion chromatographic data, water quality indices, and land usage patterns. Air, Soil and Water Research 9(1): 2020. DOI: 10.1177/ASWR.S33017

Levine S.N., Borchardt M.A., Braner M. et al. 1999. The impact of zooplankton grazing on phytoplankton species composition and biomass in Lake Champlain (USA-Canada). Journal of Great Lakes Research 25(1): 61-77.

Meng F., Li Z., Li L. et al. 2020. Phytoplankton alpha diversity indices response the trophic state variation in hydrologically connected aquatic habitats in the Harbin section of the Songhua River. Scientific Reports 10: 21337. DOI: $10.1038 / s 41598-020-78300-7$

Miller C. 2000. Daphnia pulex. Animal Diversity Web. URL: https://animaldiversity.org/accounts/Daphnia_pulex/ Last access: December 23, 2021

Mustapha M.K. 2009. Zooplankton assemblage of Oyun Reservoir, Offa, Nigeria. International Journal of Tropical Biology 57(4): 1027-1047. DOI: $10.15517 /$ rbt.v57i4.5444

Oldmeadow D.F., Lancaster J., Rice S.P. 2010. Drift and settlement of stream insects in a complex hydraulic environment. Freshwater Biology 55: 1020-1035. DOI: 10.1111/j.1365-2427.2009.02338.x

Pace M.L., Orcutt J.D. 1981. The relative importance of protozoans, rotifers, and crustaceans in a freshwater zooplankton community. Limnology and Oceanography 26(5): 822-830. DOI: $10.4319 / 10.1981 .26 .5 .0822$

Park J., Kim K., Cho C. et al. 2016. Spatio-temporal characteristics of air and water temperature change in the 
middle reach of the Nakdong River. Journal of Environmental Policy and Administration 9: 233-253. DOI: 10.11614/ KSL.2018.51.4.268

Primo A., Kimmel D., Marques S. et al. 2015. Zooplankton community responses to regional-scale weather variability: a synoptic climatology approach. Climate Research 62(3): 189-198. DOI: $10.3354 / \mathrm{cr} 01275$

Prygiel J., Coste M. 1993. The assessment of water quality in the Artois-Picardie water basin (France) by the use of diatom indices. Hydrobiologia 269 (270): 343-349. DOI: 10.1007/BF00028033

Rao A.S., Marshall S., Gubbi J. et al. 2013. Design of low-cost autonomous water quality monitoring system. In: International Conference on Advances in Computing, Communications and Informatics (ICACCI), pp. 14-19.

Redden A.M., Kobayashi T., Suthers I. et al. 2009. Plankton processes and the environment. In: Suthers I.M., Rissik D. (Eds)., Plankton: a guide to their ecology and monitoring for water quality. Collingwood, Vic, Australia: CSIRO Publishing, pp. 15-38.

Rehman M., Yousuf A.R., Balkhi M.H. et al. 2016. Dredging induced changes in zooplankton community and water quality in Dal Lake, Kashmir, India. African Journal of Environmental Science and Technology 10(5): 141-149. DOI: 10.5897/AJEST2016.2096

Santos J.M., Ferreira M.T. 2020. Use of aquatic biota to detect ecological changes in freshwater: current status and future directions. Water 12: 1611. DOI: $10.3390 /$ w12061611

Schmidt J., Andrade P.D.B., Padial A.A. 2020. Zooplankton trajectory before, during and after a hydropower dam construction. Acta Limnologica Brasiliensia 32: e18. DOI: $10.1590 /$ S2179-975X9519

Seiyaboh E., Ogamba E.N., Utibe D.I. 2013. Impact of dredging on the water quality of Igbedi Creek, Upper Nun River, Niger Delta, Nigeria. IOSR Journal of Environmental Science, Toxicology and Food Technology 7(5): 51-56.

Shah J.A., Pandit A.K. 2013. Application of diversity indices to crustacean community of Wular Lake, Kashmir Himalaya. International Journal of Biodiversity and Conservation 5(6): 311-316. DOI: 10.5897/IJBC2013.0567

Sharma S., Siddique A., Singh K. et al. 2010. Population dynamics and seasonal abundance of zooplankton community in Narmada River (India). Researcher 2(9): 1-9.

Venkatramanan S., Chung S.Y., Lee S.Y. et al. 2014. Assessment of river water quality via environmentric multivariate statistical tools and water quality index: a case study of Nakdong River Basin, Korea. Carpathian Journal of Earth and Environmental Sciences 9(2): 125-132.

Wetzel R.G. 2001. Limnology: lake and river ecosystems ( ${ }^{\text {rd }}$ ed.). San Diego, CA: Academic Press.

Xu M.Q., Cao H., Xie P. et al. 2005. The temporal and spatial distribution, composition and abundance of planktonic protozoa, with special relation to eutrophication in the Chaohu Lake, China. European Journal of Protistology 41: 183-192. DOI: 10.1016/j.ejop.2005.03.001

Zheng B.H., Tian Z.Q., Zhang L. et al. 2007. The characteristics of the hydrobios' distribution and the analysis of water quality along the west shore of Taihu Lake. Acta Ecologica Sinica 27: 4214-4223. 